Kong. Res. J. 4(1) : 92-95, 2017

ISSN 2349-2694

Kongunadu Arts and Science College, Coimbatore.

\title{
A COMPARATIVE ANATOMICAL CHARACTERISTICS OF THE STEMS OF CLIMBING PLANTS IN ARALAM WILD LEFE SANCTUARY, KANNUR
}

\author{
Prasanth, K.P1. and S.Sekaran ${ }^{2 *}$ \\ ${ }^{1} \mathrm{PG}$ and Research Department of Botany, Sree Narayana College, Kannur, Kerala. \\ ${ }^{2}$ PG Department of Biotechnology, SAS,SNDP Yogam College, Konni, Kerala. \\ *E.mail: drsekhar72@gmail.com
}

\begin{abstract}
Climbing plants differ from self-supporting plants, such as shrubs and trees, in a range of characteristics. The most notable is the mechanical properties of the stem Comparison of the differentiated anatomical structures recorded in ten species of the climbing plants. The plants selected for the present study are Ampelocissus latifolia,(Vitaceae), Lygodium flexuosum (Lygodiaceae), Centrosema virginianum(Fabaceae), Tinospora cordifolia,(Menispermaceae), Wattakakka volubilis (Asclepiadaceae) Cyclea peltata (Menispermaceae), Calycopteris floribunda (Combretaceae) Pothos scandens(Araceae) Ipomoea separia (Convolvulaceae) and Piper nigrum (Piperaceae). The stems of climbing plants are characterized by the scarcity of supporting cells (fibers) and an increase in the diameter of the xylem vessels. The study con firms that they show a greater diversity of organization than other plant life forms. This anatomical radiation could probably not exist without the achievement of a wide range of secondary growth processes. Many dicotyledons, notably those with a climbing habit, show interesting secondary structure which differs from the more usual type described, therefore, sometimes termed anomalous. The variant secondary growth is particularly widespread in tropical climbers. It is speculated that variant growth can increase stem flexibility, protect the phloem, increase storage parenchyma, aid in clinging to supports, limit physical disruption of vascular tissues during twisting and bending, and promote wound healing after girdling.
\end{abstract}

Keywords: Climbing plants, Anatomy.

\section{INTRODUCTION}

Climbing plants differ from self-supporting plants, such as shrubs and trees, in a range of characteristics. The most notable is the mechanical properties of the stem. Considering the tremendous number of possibilities for the functions and structures of stems, it is truly remarkable that there is only one single basic type in all of the vascular plants. In cross section, there is an outermost epidermis that overlies the cortex; the cortex in turn surrounds the vascular tissues. Climbing stems in primary growth with this basic type seems to be common. However, many variations of stem structure are usually called anomalies, can be seen in many climbers.

Climbing plants are found in numerous ecosystems, but are more abundant in low elevation tropical forests than in any other habitat. According to Gentry (1991), climbing plants in temperate forests represent on average $7 \%$ of the local flora, while in tropical forests this number reaches $20 \%$. Lianas are characteristic of tropical forests, where at least $50 \%$ of the trees contain lianas.
Comparison of the differentiated anatomical structures recorded in 10 species of the climbing plants confirms that they show a greater diversity of organization than other plant life forms. This anatomical radiation could probably not exist without the achievement of a wide range of secondary growth processes. Many dicotyledons, notably those with a climbing habit, show interesting secondary structure which differs from the more usual type described, therefore, sometimes termed anomalous. The anomalous or unusual structure may be a consequence of

(1) a cambium of normal type which gives rise to unusual arrangements of secondary xylem and phloem, or

(2) a cambium which itself is abnormally situated and so gives rise to abnormal arrangements of tissues, or

(3) the formation of accessory or additional cambial zone

The variant secondary growth is particularly widespread in tropical climbers. It is speculated that variant growth can increase stem flexibility, protect 
the phloem, increase storage parenchyma, aid in clinging to supports, limit physical disruption of vascular tissues during twisting and bending, and promote wound healing after girdling. Fisher and Ewers (1992) consider that the major benefits of variant xylem arrangements to climbers are not in their influence upon transport pathways, but rather in their mechanical and regeneration effects.

However, most of the information about cambial variants is based on the mature structure, and only a few developmental studies have been made (Nair 1993). Besides, as suggested by Caballé (1993), the study on the anatomical structure of liana stems should provide a highly efficient descriptive tool for the identification of taxa (families, genera or species)

The present study carried out a) To analyse the comparative stem structure of ten selected climbing species and b) To answer the inquiry whether these species present cambial variants or not and to verify the modes of cambial activities.

\section{MATERIALS AND METHODS}

In the present study the following ten climbing plants were selected from Aralam Wildlife Sanctuary.

1.Centrosema virginianum (L) Benth Family: Fabacee

2. Piper nigrum L. Family: Piperaceae

3. Ipomoea separia Roxb. Family: Convolvulaceae

4. Pothos scandens L Family: Araceaea

5. Calycopteris floribunda (Roxb.) Poir. Family: Combretaceae

6. Cyclea peltata (Lam).Hook.f.andThoms. Family: Menispermaceae

7. Wattakaka volubilis Stapf Family: Asclepiadaceae

9. Lygodium flexuosum L. (climbing fern)

Family: Lygodiaceae

10. Ampelocissus latifolia (Roxb.)Planch.

Family:Vitaceae

The stems of above mentioned plants were collected from nearby locality of Aralam wild life sanctuary, Kannur. The stems were sectioned by freehand. The cross-sections were stained using safranin (Souza et al. 2005) in agreement with usual techniques in plant anatomy (Gerrits 1991a,b). The illustrations were made by drawings (diagrams), obtained in light microscope equipped with camera lucida, and photomicrographs. Photomicrographs were obtained by processing the image captured in Olympus microscope with Cannon digital camera.

\section{RESULTS}

\subsection{Centrosema virginian(L.) Benth.}

The plants have hairs in the epidermis. But hairs are absent at the mature region of the stem. Cortex is sclerenchymatous. The stem have 13-17 vascular bundles, their distribution goes like follows, 13 vascular bundles at the $7^{\text {th }}$ internodes, 17 vascular bundles at $3^{\text {rd }}$ internodes, and 16 vascular bundles at the twisted portion. Large pith can be seen but a great controversy is seen within the pith and also in the stem. The stem of older region appears like two stems which are merged together and new branch is arises from the node as single stem and pith also shows variation in this plant. At older region the pith have a slit as it separates the two merged stems anatomically. But this slit is not seen at the younger stages. This splitting comes larger towards the base.

\subsection{Piper nigrum L.}

It is irregular in outline under microscopic observation. Ridges and grooves can be seen in the epidermis. Epidermis is followed by cortex which contains three layered collenchyma and four to five sclerenchyma then parenchyma, below it two to three layers of chlorechyama also seen. Vascular bundles are seen only in grooves, small and large vascular bundles are seen alternatly which is surrounded by wavy sclerechyama. The pith is delimited from the xylem by a wavy band of thick walled fibers. Pith is homogenous, it contain hexagonal parenchyma with medullary vascular bundles and schizogenous secretory canals are seen.

\subsection{Ipomoea separia Roxb.}

Hairs are seen in the epidermis. Heterogenous cortex. Succcessive rings of cambia can be seen. Interxylery phloem can be seen. Secondary xylem towards inner side is large. Large, homogenous, parenchymatous pith. The connective tissue is wide almost equal to vascular bundes. In mature stem vascular bundles are in different diameter.

\subsection{Pothos scandens L.}

Epidermis is seen more or less irregular with flat lateral sides and thick walled with lignified cells,circular in shape. Circular or parenchymatous ground tissue fills the cotex. Distinct layer of less thivk walled endodermis with two whorls of vascular bundles. Stellar vascular bundles scattered and densely occupied the stele and since pith cannot be differentiated. 


\subsection{Calycopteris floribunda (Roxb.)Poir.}

Hairy epidermis. Cortex is differentiated into 5-6 layers of parenchyma, sclerenchyma and chlorenchyma. In vascular bundles outer and inner cambial segment seen at certain places. In secondary xylem sclereids are seen more than vessels. Homogenous large parenchymatous pith.

\subsection{Cyclea peltata (Lam).Hook.f.andThoms.}

Single layered hairy epidermis seen. Cortex is differentiated with three types of cells, two layers of collenchyma and chlorenchyma, wavy sheath of sclerenchyma present at the end. 8-10 vascular bundles seen. Secondary xylem is enormous. Pith is small in primarystructure but large in secondary structure.

\subsection{Wattakaka volubilis Stapf}

Wavy outline,hairs are present. Cortex have three layers of collenchyma, three layers of chlorenchyma and three layers of sclerenchyma. About 10-12 vascular bundles are seen, large and small vascular bundles are seen alternately. In secondary structure smallround bundles of phloem is seen in secondary cortex which is $12-15$ layered chlorenchyma cells. In secondary xylem morevessels are seen in protoxylem region but in metaxylem region sclereids are seen.

\subsection{Tinospora cordifolia Miers}

Single layered epidermis. Below the epidermis collenchymatous cells seen which is starting of the cortical layer. Collenchyma cells are followed by three to four layered wavy sclerenchymatous cells, which foam a continuous ring. Parenchymatous cells are seen below this, the elongated cells become widened as we go towards pith. In mature stem pericyclic sclerenchyma and phloem persist in original. Arround 9 vascular bundles can be seen in primary structure. Vascular bundles differ in size alternatly. The fascicular and interfascicular cambium seen between the two vascular bundles. Vascular bundles. Vascular bundles increas in size and number as the stem grows older. Parenchymatous large pith with suberin deposition.

\subsection{Lygodium flexuosum $L$.}

Outermost epidermis, followed by sclerenchymatous cells. Parenchymatous cortex is present. And stele is protostel. The vascular bundle are arised from supernumerary cambial tissue. In secondary structure it has numerous vascular bundles. Large round pith, and pith is constricted in twisted rwgion.

\subsection{Ampelocissus latifolia (Roxb.) Planch.}

Hairy epidermis which is irregular in outline. Trichomes are also seen. Epidermis is followed by collenchyma. Sclerenchymatous cells, which is six layered is seen just below the grooves and this is followed by chlorenchymatous cells and rounded parenchyma. Bicollateral vascular bundles seen. Large vessels are seen at the innermost vascular bundles but small vessels are seen in the peripheral vascular bundles. Pith is almost absent in mature portion.

\section{DISCUSSION}

Climbing plants present numerous morphological and anatomical characteristics that distinguish them from other forms of plant life. Among these characteristics are the anatomical structure of the stems and the climbing and attachment mechanisms. Vines have long and flexible stems that depend on external support to maintain themselves erect or to reach illuminated areas in their habitat.

The stems of climbing plants are characterized by the scarcity of supporting cells (fibers) and an increase in the diameter of the xylem vessels, which may be visible to the naked eye. The increase in the diameter of the xylem vessels triplicates the conduction of water, making climbers able to maintain a great quantity of leaves in relation to the total diameter of their stems. (Ampelocissus latifolia) These stems that are specialized for the conduction of water are known only in plants that possess xylem vessels (elements with perforated walls), and are absent in those that have only tracheids or imperforate elements. Imperforate elements obviously represent an obstacle to the free flow of water, slowing it down and making water transport over great distances difficult.

The stems of climbing plants face structural challenges that differ from those experienced by trees and shrubs. They are subjected to tensile and compacting forces, due to the movement of the structures (usually small trees) that support them. For this reason their stem construction, with an alternation of vascular and parenchymatous tissues, gives them considerable flexibility to withstand these types of pressure (Ampelocissus latifolia, Tinospora cordifolia and Cyclea peltata). In addition, the stems of climbing plants are subject to friction against the host trees that can cut or tear irregularly their bark and thus wound the phloem tissue. Many lianas have encountered a solution to this problem by having phloem tissue inside the xylem. (Tinospora cordifolia 
and Calycopteris floribunda). The arrangement of phloem tissue in relation to the xylem can produce patterns sometimes considered anomalous, which serve to characterize families or genera of climbers.

Alternation of bands of vascular tissue with connective tissue. This pattern is the result of the activity of successive bands of cambium that produce a band of vascular tissue (xylem and phloem) accompanied by a band of connective tissue (parenchyma). The cambial activity is repeated to produce successive concentric bands of vascular tissue and connective tissue. The connective tissue can be as wide as the vascular tissue, thus producing a conspicuous pattern of alternating bands. This pattern can be observed in Ipomoea separia of the family Convolvulaceae.

Non-concentric bands. This pattern, like the previous one, is the result of the activity of successive bands of cambium. In this case, however, the activity of the cambial tissue gives rise to asymmetric bands, which develop primarily toward only one sector of the stem, thus producing a stem whose pith is not in a central position. Examples of this pattern are seen in the Centranthera of the family Fabaceae, and in the Cyclea peltata of the family Menispermaceae.

Discrete vascular bundles. This pattern is the result of the activity of successive bands of cambium, which produce discrete bundles of xylem and phloem surrounded by parenchyma cells. The resulting pattern is that of collateral bundles dispersed in connective tissue (parenchyma). Examples of this type of pattern are found in Tinospora cordifolia

In one pattern, the peripheral vascular cylinders are of a smaller diameter than the central cylinder and can be seen both in young stems and in mature ones. Vascular Bundles are of different diameters. This pattern is visible only in mature stems. Examples are found in the genus Ipomoea separia

Compressed stem pattern, with the vascular cylinder in a central position, is obtained through asymmetrical secondary growth, in which the stem grows laterally in two opposing directions. Examples of this pattern are found in Centrosema virginianum.

In the climber, Ampelocissus latifolia, the aerial stem includes young stems with parenchymatous cortex and a cylinder vascular, as well as older stages with significant secondary growth of the vascular cambium and periderm.
Structure and development of included phloem was investigated in the stems of Calycopteris floribunda. After the definite period of cambial activity, cells in the middle of the cambial zone began to differentiate into thin walled cambial derivatives which separated the cambium into outer and inner cambial segment at certain places. Rest of the cambium along with separated outer segment remained functionally active while inner segment became temporarily nonfunctional. Original circular outline of the cambial cylinder was restored by joining of outer segment with existing one whereas inner cambial segment got embedded resulting in production of an islands of included phloem in the secondary xylem. This process was repeated several times resulting in a number of phloem islands surrounded within thick walled secondary xylem. Differentiation of phloem elements was initiated only after the formation of thick walled xylem derivatives from the outer cambial segment. The segments of the cambium producing the phloem island remained active for fairly long time. Sieve tube elements of the phloem islands situated deep inside the older stem became non-functional and underwent obliteration after heavy accumulation of callose. Secondary xylem was diffuse porous with indistinct growth rings and composed of vessels (both wider and fibriform vessels), nucleated xylem fibers, axial and ray parenchyma.

\section{ACKNOWLEDGEMENT}

We thank UGC for the financial support granted to the accomplishment of this work.

\section{REFERENCES}

Fisher, J.B. and E.W. Ewers (1992). Xylem pathways in liana stems with variant secondary growth. Bot. J. Linn. Soc. 108:181-202.

Gentry, A.H. (1991a). The distribution and evolution of climbing plants. In: Putz, F.E. and Mooney, H.A. (eds.) The biology of vines. pp. 3-49. Cambridge University Press, Cambridge, UK

Gerrits, P.O. (1991b). The application of histotechnology: some fundamental principles. University Groningen, Netherlands 326 pp.

Nair, M.N. (1993). Structure of stem and cambial variant in Spatholobus roxburghii. IAWA. Journal 14; 191-204.

Souza, L.A., S.M. Rosa, I.S. Moscheta and G.A. Lolis (2005). Morphological and anatomical Techniques. Ponta Grossa.192.pp. 